\title{
SELENOENZYME-GLUTHATHIONE PEROXIDASE (GSH-Px) ${ }^{1}$
}

\author{
Mirjana Joksimović-Todorović, Vesna Davidović
}

Abstract: Selenium is a natural antioxidant but it has an important role in various physiological processes in organism. It enables the functioning of immune system and prevents development of malignant diseases.

Some diseases of farm animals (exudative diathesis, muscular dystrophy, pancreas atrophy, hepatosis dietetica, etc.), reduced productive and reproductive abilities are the effects of selenium deficiency.

Biological role of selenium is manifested by the enzyme of glutathione peroxidase (GSH-Px), which contains selenium in its nexus. Recently the researchers have identified four forms of this enzyme called the family of enzymes. They are present in almost all cellulars, but their distribution in tissues is varied. Some factors (individual, age, sex, etc.) influence the activities of enzymes in different organs. Seasonal and cyclic changes can also influence enzyme activities. Endocrine system is the one that controls its activity and recently some researchers have also suggested a genetic regulation.

Key words: selenium, seleno proteins, glutathione peroxidase.

\section{Introduction}

Enzymology and the role of GSH-Px was first described by Flohe and Schlegel (1971), while Rotruck et al., (1973) had isolated this enzyme from the rat liver and confirmed that it contained selenium. Flohe et al. (1973) had purified the enzyme to a crystallized state and determined that the content of selenium was 4 g-atoms per mol of enzyme. By the mid 1980s a number of selenoproteins was discovered when biochemistry of selenium increasingly became a topic of interest. Until now about 50 selenoproteins have been identified by the use of electrophoretic isolation. However, the function of all isolated selenoproteins is still not explained.

Selenium-dependent glutathione peroxidase (Se GSH-Px) has a role to protect cell system from damages caused by the action of oxygen. A presence of free oxygen and its radicals has a harmful effect on cellular system. Reaction between oxygen and electrons produces a number of intra-products which can have a detrimental effect on cells. Superoxide $\left(\cdot \mathrm{O}_{2}{ }^{-}\right)$and peroxide $\left(\cdot \mathrm{HO}_{2}{ }^{-}\right)$are the most important in that process since one unpaired electron from these intra-products, under certain conditions, can provoke a reaction with cell organic components. The site of action of these radicals is mostly bivalent bonds of unsaturated fatty acids, either free or incorporated into cells. A free radical reacts with unsaturated fatty acid and makes a lipid free radical (R.). Then there occurs the rearrangement of bivalent bonds, tying of molecule oxygen and creation of fatty acid peroxil-radical (ROO-). It attracts hydrogen from the other molecule of unsaturated fatty acid and forms hydro peroxide of unsaturated fatty acid $(\mathrm{ROOH})$ and a new free radical. In this way a chain reaction has been established (Combs and Combs, 1986).

In numerous trials conducted on various kinds of farm animals a dependence of the activity of GSHPx on the level of intaken selenium has been established (Cantor and Tarino, 1982: Sankari and Atroshi 1983, Sankari 1985, Hassan 1987, Todorović 1990, Mihailović et al., 1991). Because of that the activity of GSH-Px in blood plasma is a reliable indicator of the status of selenium in animals, but only in suboptimal and optimal levels of selenium. A high selenium levels do not lead to proportional increase of this selenoenzyme (Meyer et al., 1981, Mihailović et al., 1996a,b, 1997). Depending on the form of given selenium, when levels are increasing above needed ones, the activity of this enzyme shows the effect of plateau so that higher contents of selenium do not result in further increase of activity (Todorović, 1997).

Prohaska and Ganther (1977) and Lawrence and Burk (1978) established the existence of seleniumindependent GSH-Px whose activity increases with the presence of selenium deficiency. Activity of this enzyme comes from glutathione S-transferase. Its existence can partly explain different reactions of tissues in case of selenium and vitamin E deficiency.

1 Review paper (Pregledni rad)

2 Dr Mirjana Joksimović-Todorović, associate professor, Vesna Davidović, doctor in veterinary medicine, assistant, Faculty of Agriculture, Zemun. 


\section{Selenoproteins-glutathione peroxidases}

Four forms of glutathione peroxidases are known. Cytoplasmic (GPX-1) is present is all body cells. It is thought that it is the most important enzyme in preventing the detrimental effects of oxidative stress (Kohrle et al., 2000). It is involved in various physiological events such as differentiation, signal transduction and regulation of pro-inflammatory cytokine production (Ursini, 2000), and takes part in biosynthesis of leukotrienes, thromboxanes and prostaglandins responsible for the modulation of inflammatory reactions. It is thought that it can bring about the process of transcription (Kohrle et al., 2000).

A second enzyme glutathione peroxidase (GPX-2) is also being synthetized in cytoplasm and it has a tetrameric structure. This enzyme is mostly present in gastrointestinal tract. It represents a major barrier against hydroperoxide resorption (Brigelius-Flohe, 1999). It suggests that the digestive tract is a major site of antioxidant and prooxidant interaction in the body (Surai, 2002). Intestinal GSH-Px is a main protector against hydroperoxide originating from nutrition. During feed production and storage some unsaturated lipids are oxidised and they can cause health-related problems, including decreased growth, impaired productive and reproductive function and immune competence (Kanazawa and Ashida, 1998). Indeed, oxidized lipids can react with transition metals, already present in the feed or as feed supplements producing free radicals. Those free radicals can react with natural or synthetic antioxidants present in the feed. Intestinal GSH-Px prevents, them, in this way, entering systemic circulation. Besides (GPX-2) in the gastrointestinal tract there are three more selenoproteins present including plasma GSH-Px, selenoprotein $\mathrm{P}$ and thioredoxin reductase (Mork et al., 1998).

Phospholipid hydroperoxide glutathione peroxidase (GPX-3) can metabolize phospholipid hydroperoxides whereas (GPX-1) cannot. The major source for this enzyme is the kidney and the mRNA for a dominant site of its synthesis is in the proximal tubules of kidney. This enzyme can also be found in plasma and extracellular fluids.

The fourth Se-dependent glutathione peroxidase (GPX-4) is significantly different from the (GPX-1) enzyme. This enzyme has a monameric protein structure (it contains $1 \mathrm{~g}$ atom of selenium per enzyme mol) and it is not glutathione specific, such that it can use phospholipids hydroperoxides as substrates. It is believed that this enzyme is able to bind to a wider range of substrates than the other GPX enzymes. Although its function has not been clearly defined, it is thought that it may protect cellular membranes and mitochondrial intermembrane spaces.

Despite great attention paid to GSH-Px family of enzymes it seems likely that thioredoxin reductase, described as selenoprotein (Gladyshev et al., 1996) may be of even greater significance than GSH-Px. The redox status of the cell is a major determinant of many different pathways including gene regulation (Morel and Barouki, 1999). A thiol redox system consists of the glutathione system (glutathione/glutathione reductase/glutaredoxin/glutathione peroxidase (Cotgreave and Gerdes, 1998)) and a thioredoxin system (thioredoxin/thioredoxin peroxidase/thioredoxin reductase). It is believed that these two systems play an important role in the regulation of different processes (Holmgren, 2000). Together they supply electrons for deoxyribonucleotide formation, antioxidant defence and redox regulation of signal transcription, transduction and controlled cell destruction (Mustacich and Powis, 2000). The thioredoxin reductase (TR) can reduce not only thioredoxin but also oxidized glutathione (Sun et al., 2001). The thioredoxin reductase family (TR) is involved in thiol redox regulation, DNA synthesis, regulation of gene transcription and regulation of growth (Burk, 2002).

The iodothyronine deiodinases is a family of three enzymes responsible for the maintenance of thyroid hormone homeostasis.

Sperm capsule selenoprotein (SCS) is localized in the midpiece of the spermatozoa where it stabilizes the integrity of the sperm flagella (Brown and Arthur, 2001). Selenoprotein (SCS) is responsible also for sperm motility, viability and fertilizing capacity (Kohrle et al., 2000).

\section{The effect of selenium level in feed on the activity of glutathione peroxidase}

A selenium supplementation of feed (optimal and suboptimal levels) can lead to increasing the activity of selenoenzymes (GSH-Px) in blood plasma. The chicks fed diets supplemented by 0,5 or $1 \mathrm{mg} \mathrm{Se} / \mathrm{kg}$ feed had higher enzyme activity in comparison with chicks fed no such supplementation (Todorović, 1990). 
However, the adding of high levels of organic or inorganic selenium form $(2,5,10,15$ or $20 \mathrm{mg}$ $\mathrm{Se} / \mathrm{kg}$ feed) in the first seven days posthatch leads to increased activity, but in later periods of fattening the activity declines significantly so that at the end it was reduced to one third of the initial value (Todorović et al., 1998; Joksimović-Todorović and Jokić, $2005 a, b$ ). Initial high selenium levels lead to increasing enzyme activity but in later periods activity abruptly declines. It seems likely that cells which synthetize enzyme become in time seriously damaged by a high selenium levels so that in the beginning they decrease and later completely terminate the synthesis. On the contrary, Stanley and Tappel (1974) confirmed a linear increase of the activity of enzymes in chicks blood plasma. The authors reported that by adding 1,4 , ie., 4,6 $\mathrm{mgSe} / \mathrm{kg}$ in diet the activity of enzymes was approximately the same, whereas $14 \mathrm{mg} \mathrm{Se} / \mathrm{kg}$ feed caused the increase in the enzyme activity by $100 \%$ in relation to previously reported values.

The activity of enzyme does not depend only on the level of feed supplemented selenium. The nutrition is one of important factors (content of fat, fatty acids, microelements, vitamins) which besides selenium influences enzyme activity (Erdélyi et al., 1999). There are also some individual factors such as body weight, age, sex, endocrine system, which are found to regulate the activity of selenoenzymes (Miklós et al., 2003).

\title{
Conclusion
}

Selenium supplementation in organism is being turned into some metabolic forms necessary for physiological functions. During these metabolic processes some products are generated in the form of specific selenoproteins. Besides selenoenzyme GSH-Px which has a special physiological function, a presence of many more other selenoproteins was confirmed but their role is still unknown. It seems likely that some of them represent selenium depots in the organism.

\section{SELENOENZIM - GLUTATION PEROKSIDAZA (GSH-Px)}

\author{
Mirjana Joksimović-Todorović, Vesna Davidović
}

Rezime

Selen je prirodni antioksidans, ali ima važnu ulogu i u brojnim fiziološkim procesima u organizmu, omogućava funkcionisanje imunološkog sistema i sprečava razvoj malignih oboljenja.

Pojedina oboljenja domaćih životinja (eksudativna dijateza, mišićna distrofija, atrofija pankreasa, hepatosis dietetica i dr.), smanjena proizvodna i reproduktivna svojstva su posledica deficita selena.

Svoju biološku ulogu selen obavlja preko enzima glutation peroksidaze (GSH-Px), koji u svom centru sadrži selen. Definisane su četiri forme ovog enzima, koje se danas nazivaju familijom enzima. Prisutni su skoro u svim ćelijama organizma ali njihova distribucija u tkiva pokazuje izvesna variranja. Pojedini faktori (individualni, starost, pol jedinke idr.) utiču na aktivnost enzima u pojedinim organima. Sezonske i ciklične promene takođe menjaju aktivnost enzima. Endokrini sistem kontroliše njegovu aktivnost a u poslednje vreme govori se i o genetskoj regulaciji.

\section{Literature}

24. BRIGELIUS-FLOHE R. (1999): Tissue-specific Functions of Individual Glutathione Peroxidases, Free. Rad. Biol. Med. 27, 951-965.

25. BROWN K.M. and ARTHUR J.R. (2001): Selenium, Selenoproteins and Human Health: a Review. Public Health Nutr. 4, 593-599.

26. BURK R.F. (2002): Selenium, an antioxidant nutrient. Nutr. Clin. Care. 5, 75-79.

27. CANTOR A.H. and TARINO J.Z. (1982): Comparative effects of inorganic and organic dietary sources of selenium on selenium levels and selenium dependent glutathione peroxidase activity in blood of young turkey. J. Nutr. 112, 2187-2196. 
28. COMBS G.F.Jr. and COMBS S.B. (1986): The role of selenium in nutrition. Academic Press, Inc. Harcourt Brace Jovanovich, Publishers, Orlando, San Diego, New York, Austin, Boston, London, Sydney, Tokyo and Toronto.

29. COTGREAVE I.A. and GERDES R.G. (1998): Recent Trends in Glutathione Biochemistry-GlutathioneProtein Interactions: a Molecular Link Between Oxidative Stress and Cell Proliferation. Biochem. Biophys. Res. Commun. 242, 1-9.

30. ERDÉLYI M., MÉZES M. and VIRÁG Gy. (1999): Selenium dependent glutathione peroxidases in animals. I. Structure, function, regulation (in Hungarian). Biokémia 23, 82-88.

31. FLOHE L. and SCHLEGEL W. (1971): Glutathion-peroxidase. IV Hoppe-Seyler's 2. Physiol. Chem., $352,1401,1971$.

32. FLOHE L., GUNZLER W.A. and SHOCK H.W. (1973): Glutathione peroxidase: a selenoenzyme, FEBS Letts, 32, 132.

33. GLADYSHEV V.N., Jeang KT, Stadtman TC. (1996) Selenocysteine, identified as the penultimate Cterminal residue in human T-cell thioredoxin reductase, corresponds to TGA in the human placental gene. Proc Natl Acad Sci U S A . 1996 93> 6146-6151.

34. HASSAN S. (1987): Bioavailability of selenium in feed stuffs as studied in the chick. Swedish university of Agricultural Science 1-65.

35. HOLMGREN A. (2000): Redox Regulation by Thireodoxin and Thioredoxin Reductase. Biofactors 11, 63-64.

36. JOKSIMOVIĆ TODOROVIĆ MIRJANA and JOKIĆ Ž. (2005): Uticaj visokih nivoa neorganskog selena na aktivnost glutation peroksidaze (GSH-Px) u krvnoj plazmi brojlera. Biotehnologija u stočarstvu. Br. 3-4 (in press).

37. JOKSIMOVIĆ TODOROVIĆ MIRJANA and JOKIĆ Ž. (2005): Uticaj visokih nivoa organskog selena na aktivnost glutation peroksidaze (GSH-Px) u krvnoj plazmi brojlera. Veterinarski glasnik 3-4 (in press).

38. KANAZAWA K. and ASHIDA H. (1998): Catabolic fate of dietary trilinoleoleoylglycerol hydroperoxides in rat gastrointestines. Biochem. Biophys. Acta 1393, 336-348.

39. KOHRLE J., BRIGELIUS-FLOHE R., BOCK A., GARTNER R., MEYER O. and FLOHE L. (2000): Selenium in Biology: Facts and Medical Perspectives. Biol. Chem. 381, 849-864.

40. LAWRENCE R.A. and BURK R.F. (1978): Species, tissue and subcellular distribution of non Sedependent glutathione peroxidase activity. J. Nutr. 108, 211-215.

41. MEYER W.R., MAHAN D.C.and MOXON A.L. (1981): Value of dietary selenium and vitamin E for weanling swine as measured by performance and tissue selenium and glutathione peroxidase activities. J. Anim. Sci. 52, 302.

42. MIHAILOVIĆ M., TODOROVIĆ MIRJANA and ILIĆ V. (1991): Efect of dietary selenium on GSH-Px activity and body weight of growing turkeys. Acta Veterinaria vol. $41 \mathrm{~N}^{\mathrm{O}} 2-3$, pp 75-80.

43. MIHAILOVIĆ M., TODOROVIĆ MIRJANA, JOVANOVIĆ M., PALIĆ T., JOVANOVIĆ I., PEŠUT OLIVERA and KOSANOVIĆ M. (1996a): Toxicity of sodium selenite and selenized yeast to chickens. The sixst Internat. Symp. on selenium in Biol. and Med. Peking NR Kina Program and Abstracts pp.125.

44. MIHAILOVIĆ M., TODOROVIĆ MIRJANA, JOVANOVIĆ M., PALIĆ T., JOVANOVIĆ I., PEŠUT OLIVERA and KOSANOVIĆ M. (1996b): Toxicity of organic and inorganic selenium to chickens. Ninth Internat Symp. of Trace Elements in Man and Animals (Tema 9)-Banff Alberta-Canada 1996. Trace Elements in Man and Animals 9, 554-555.

45. MIHAILOVIĆ M., TODOROVIĆ MIRJANA, JOVANOVIĆ M., PALIĆ T., JOVANOVIĆ I. and PEŠUT OLIVERA (1997): Toxicity of selenium to broilers. $\mathrm{XI}^{\text {th }}$ International Congres of the World. Poultry Association 18-22 August, Budapest, Hungary.

46. MIKLÓS M., MÁRTA E., GIHAN S., GYÖRGYI V., KRISZTIÁN B. and MÁRIA W. (2003): Genetics of glutathione peroxidase. Acta Biologica Szegediensis. Vol. 47 (1-4), 135-138.

47. MOREL Y. and BAROUKI R. (1999): Repression of Gene Expression by Oxidative Stress. Biochem J. 342, 481-496

48. MORK H.B., LEX M., SCHEURLEN I., DREHER N., SCHUTZE J., KOHRLE J. and JAKOB F. (1998): Expression Pattern of Gastrointestinal Selenoproteins-Targets for Selenium Supplementation. Nutr. Cancer 32,64-70.

49. MUSTACICH D. and POWIS G. (2000): Tireodoxin Reductase. Biochem J. 346,1-8. 
50. PROHASKA T.R. and GANTHER H.E. (1997): Glutathione peroxidase activity of glutathione-Se transpherase purified from rat liver. Biochem. Biophys. Res. Commun 76, 437-445.

51. ROTRUCK J.T., POPE A.L., GANTHER H.E., SWANSON A.D., HAFEMAN D.G. and HOEKSTRA W.G. (1973): Selenium biochemical role as a component of glutathione peroxidase. Science 179, 588 .

52. SANKARI S. and ATROSHI F. (1983): Effect of dietary selenium on erythrocyte glutathione peroxidase and blood in two types of Finnisheep genetically selected for high and low glutathione perozidase activity. Zbl. Vet. Med. A., 30, 542.

53. SANKARI S. (1985): Plasma glutathione peroxidase and tissue selenium response to selenium supplementation in swine. Acta. Vet. Scand. 81, 1-127.

54. STANLEY T. and TAPPEL A.S. (1974): Effect of Dietary Selenium on Glutathione Peroxidase in Chicks. J. Nutr. 104, 747-753.

55. SUN Q. A., KIRNARSKY L., SHERMAN S. and GLADYSHEV V. N. (2001): Selenoprotein oxidoreductase with specificity for Thioredoxin and Glutathione Systems. Proc. Natl. Acad. Sci. USA 98, 3673-3678.

56. SURAI P.F. (2002): Selenium in poultry nutrition: a new look at on old element. Antioxidant properties, deficiency and toxicity. World's Poultry Sci. J. 58, 333-347.

57. TODOROVIĆ MIRJANA (1990): Uticaj deficita selena na aktivnost glutation peroksidaze, alkalne fosfataze i prirast ćurića u tovu. Magistarski rad, Beograd.

58. TODOROVIĆ MIRJANA (1997): Toksičnost selena kod pilića u tovu. Doktorska disertacija, Beograd.

59. TODOROVIĆ MIRJANA, MIHAILOVIĆ M. and HRISTOV S. (1998): Uticaj visokih nivoa natrijum selenita na aktivnost nekih enzima u krvnoj plazmi pilića. Vet.glasnik, vol.52. Br 7-8, 417-424.

60. URSINI F. (2000): The World of Glutathione Peroxidases. J. Trace Elem. Med. Biol 14, 116. 